\title{
Bacterial ascending mediastinitis following diagnostic pleuroscopy in a patient with pleural tuberculosis
}

\author{
Bakteryjne wstępujące zapalenie śródpiersia w następstwie \\ diagnostycznej pleuroskopii u pacjentki z gruźlicą opłucnej
}

\author{
Sławomir Jabłoński, Piotr Misiak \\ Department of Thoracic Surgery, General and Oncological Surgery, Medical University of Lodz, Poland
}

Kardiochirurgia i Torakochirurgia Polska 2012; 9 (4): 486-489

\begin{abstract}
Descending necrotizing mediastinitis is an emergency surgical condition with a high mortality rate. The inflammatory process spreads downwards along the neck fascial space from primary infection foci from the oro-pharynx. Usually mediastinitis of bacterial etiology is polymicrobial in nature and presents with an acute course. Mediastinitis of specific etiology, characterized by chronic course and causing mediastinal fibrosis, is rare. The study presents an atypical case of iatrogenic acute mediastinitis, which developed in an ascending mechanism in a patient after diagnostic left pleuroscopy performed due to parietal pleural pathology with accompanying pleural effusion. Histopathological examination of the pleural specimens revealed pleural tuberculosis.
\end{abstract}

Key words: acute mediastinitis, pleuroscopy, pleural tuberculosis.

\section{Introduction}

The diagnostics of pleural disease with effusion is difficult and not always effective [1, 2]. It is important for the patient's prognosis to differentiate whether the observed changes result from inflammatory processes (specific and non-specific), primary and secondary neoplasms, or they are the consequence of transudative effusions in heart failure, liver, kidney or other diseases. When conventional pulmonological diagnostic possibilities have been exhausted, including thoracocentesis to perform biochemical tests, bacteriological cultures and cytology as well as closed pleural biopsy (CPB), the next step is qualification for diagnostic thoracoscopy or videothoracoscopy. Thoracoscopy, also known as pleuroscopy, is a minimally invasive procedure to inspect and perform a biopsy of the pleural space as well as to perform chosen therapeutic interventions [3].

\section{Streszczenie}

Zstępujące zapalenie śródpiersia jest zaliczane do nagłych stanów chirurgicznych związanych z wysoką śmiertelnością. Proces zapalny rozprzestrzenia się gwałtownie w dół wzdłuż przestrzeni powięziowych szyi z pierwotnego ogniska infekcji położonego w jamie ustnej bądź gardle. Bakteryjne zapalenie śódpiersia ma z reguły ostry przebieg i jest z natury polimikrobiologiczne. Swoiste zapalenie śródpiersia jest bardzo rzadkie, cechuje je przewlekły przebieg, który prowadzi do zwłóknienia śródpiersia. W pracy przedstawiono nietypowy przypadek jatrogennego zapalenia śródpiersia, który rozwinął się w mechanizmie wstępującym po wykonaniu diagnostycznej pleuroskopii u pacjentki z patologią opłucnej ściennej i towarzyszącym wysiękiem. W badaniu histopatologicznym wycinków z opłucnej rozpoznano gruźlicę.

Słowa kluczowe: zapalenie śródpiersia, pleuroskopia, gruźlica opłucnej.

This minimally invasive procedure can be the cause of both typical and rarely observed complications. The study presents an atypical case of iatrogenic mediastinal infection which developed in an ascending mechanism after diagnostic pleuroscopy performed in a patient with one-sided pleural tuberculosis.

\section{Case report}

A 66-year-old woman (WH) was referred for diagnostic pleuroscopy due to recurrent effusion and parietal pleural pathology limited to the left pleural cavity of unestablished etiology. The patient was hospitalized twice at the Department of Pneumonology with a history of effort intolerance, dyspnea, cough, hyperhidrosis, subfebrile body temperature, heartburn, nausea, abdominal distension and general weakness. During the first hospitalization (3 months ago)

Address for correspondence: Sławomir Jabłoński, 17 Daleka St., 93-348 Łódź, Poland, tel. +48 4263935 21, mobile telephone: +48 502 202 704, Fax: +48 4263338 90, Email: jablonski_s@vp.pl 
chlamydial pneumonia with effusion to the left pleural cavity was diagnosed. After conservative therapy including antibiotic therapy, improvement was observed. Further treatment was continued on an outpatient basis. As the pleural effusion persisted, the patient was rehospitalized (4 weeks ago), thoracocentesis was performed three times, and $2 \times 1000 \mathrm{ml}$ and $300 \mathrm{ml}$ of yellow serous fluid were removed. Thoracic CT showed effusion and parietal pleural thickening on the left.

No etiology of the disease was established despite the performed diagnostics of the fluid including biochemical, cytological and microbiological examinations. The cytological examination of the pleural effusion fluid showed reactive changes in mesothelial cells, macrophages and lymphocytes.

The patient presented the following coexisting diseases: arterial hypertension, chronic gastritis and hypothyroidism. Four years ago the patient underwent right hemicolectomy for a benign cecal tumor (leiomyoma).

Physical examination showed the following deviations from normal patterns: diminished breath sounds over the left lung field; thyroid nodular goiter. No deviations were found in standard laboratory investigations performed preoperatively.

\section{Pleuroscopy technique}

Pleuroscopy was performed under general anesthesia with double-lumen endotracheal intubation. The patient was placed in a decubitus position with the involved left side

Tab. I. Values of inflammatory markers in the course of treatment

\begin{tabular}{lccc} 
& $\begin{array}{c}\text { WBC } \\
\left(* 10^{3} / \mu \mathrm{l}\right)\end{array}$ & $\begin{array}{c}\text { CRP } \\
(\mathrm{mg} / \mathrm{l})\end{array}$ & $\begin{array}{c}\text { PCT } \\
(\mathrm{ng} / \mathrm{ml})\end{array}$ \\
before pleuroscopy & 5.1 & 16 & 0.08 \\
\hline $2^{\text {nd }}$ day after pleuroscopy & 18.7 & 194 & 1.48 \\
\hline end of hospitalization & 13.8 & 79.9 & 0.51 \\
\hline WBC - white blood cell count; CRP - C-reactive protein; $P C T$ - procalcitonin
\end{tabular}

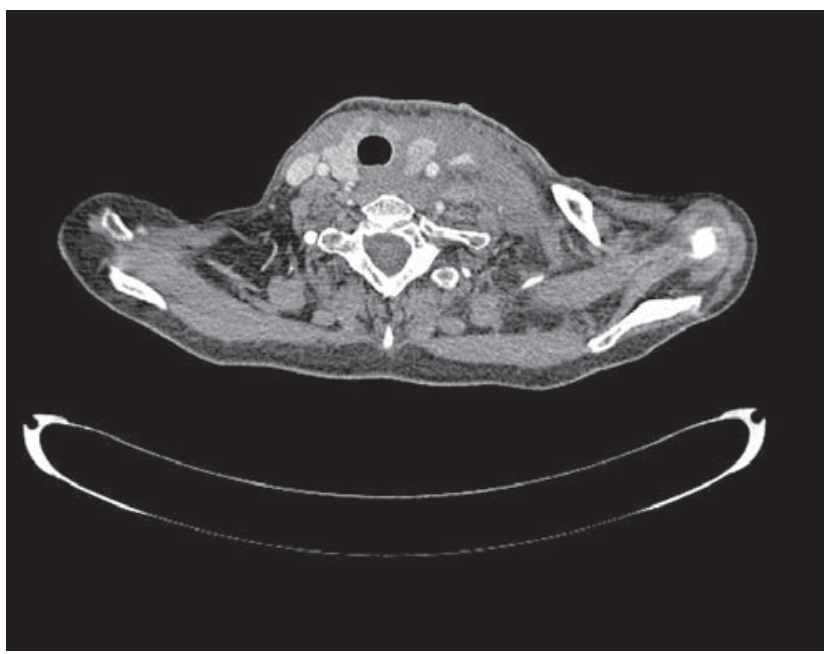

Fig. 1. Neck computed tomography: inflammatory infiltration outside the left lobe of the thyroid, fluid and gas collections seen in soft tissues upward. A $10 \mathrm{~mm}$ incision was made along the mid-axillary line in the $5^{\text {th }}$ intercostal space and a rigid pleuroscope (Storz) was advanced into the pleural space after blunt dissection. About $500 \mathrm{ml}$ of pale yellow fluid was aspirated and sent for cytological examination. The surface of parietal, mediastinal and diaphragmatic pleura were invaded by small, milky nodular lesions of soft structure. To obtain a collapsed lung, mild edema was created by administering carbon monoxide under the pressure of 8-10 $\mathrm{mm} \mathrm{Hg}$ into the pleural cavity. Using forceps a few pleural samples with nodules were collected from the pleural cavity apex and from the mediastinal area. Due to recurrent effusion and the range of changes occurring in the pleura, chemical pleurodesis was performed by introducing a mixture of $20 \mathrm{ml}$ of $10 \%$ iodopovidone and $80 \mathrm{ml}$ of normal saline into the pleural space. The patient responded well to the procedure.

On day 1 after surgery the temperature was $38.4^{\circ} \mathrm{C}$. The patient complained of neck pain which was the cause of further hospitalization. On the next day extensive neck swelling and reddening, soft tissue crepitus and tenderness on palpation were observed. Additional symptoms appeared: odynophagia, dysphagia and dyspnea. Laboratory investigations revealed high values of inflammation markers: WBC (white blood cell count), CRP (C-reactive protein) and PCT (procalcitonin) (Table I).

Neck ultrasonography (USG) showed inflammatory infiltrate in neck soft tissues, bilateral infiltrate of $15 \mathrm{~mm}$ diameter with free fluid collections.

Neck and chest computed tomography (CT) result (Figs. 1,2 ): in soft tissues of left side of the neck, large air and fluid collections were visible extending from C4 to the temporal bone. Around these lesions were multiple small air bubbles which were also found in the mediastinum at the level of the Th3 vertebra. The left thyroid lobe was shifted and surrounded by circumscribed inflammatory infiltrate. In the mediastinum, along the vascular space, an air collection was observed passing through the superior thoracic aperture and connecting with the lumen of the nasopharynx. Left neck

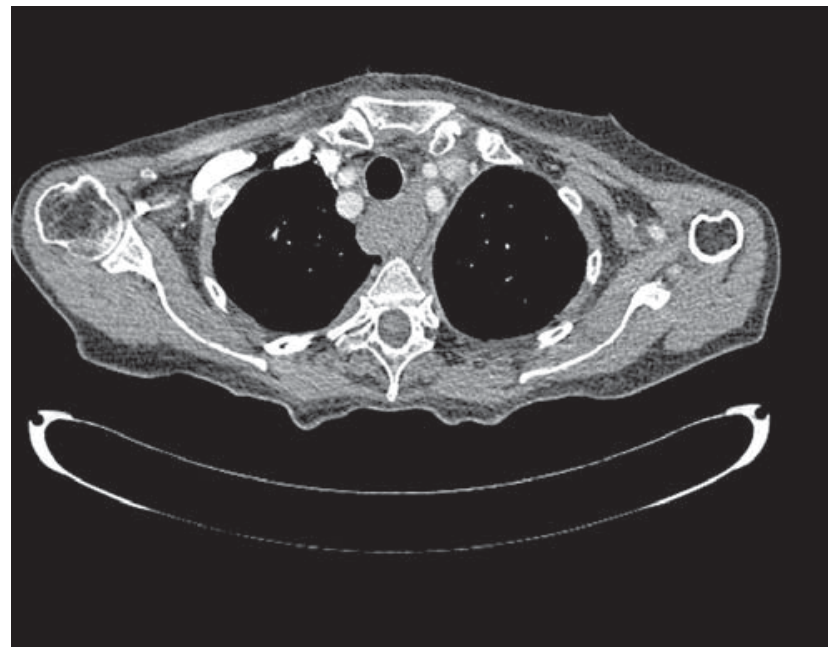

Fig. 2. Thoracic computed tomography: circumscribed fluid collection in posterior mediastinum 
structures were surrounded by high density fluid, soft tissues with the features of edema and inflammatory infiltration.

The patient was qualified for urgent surgery. Debridement, toilette and drainage of the infected fluid collections were performed in the neck and upper mediastinum through left-sided cervicotomy. The maintenance treatment was continued in the intensive care unit. After the next 4 days, due to ineffective cervical and mediastinal drainage, another cervicotomy was performed with debridement and neck soft tissue and fascial spaces drainage as well as right-sided thoracotomy with extensive drainage of the posterior mediastinum. After the second procedure, normalization of the patient's general condition was observed and the withdrawal of the mediastinitis confirmed by the results of imaging diagnostics and the decreased levels of inflammatory markers (Table I).

Histopathological examinations of pleural specimens revealed pleural productive and caseous tuberculosis. Histopathological examination of the tissues from the cervical abscess in the area of the left thyroid lobe revealed nonspecific inflammatory infiltration of soft tissues. The result of the culture of pleural fluid collected during pleuroscopy indicated Staphylococcus epidermidis and Candida albicans.

The result of the analysis of swab collected from the area of the cervical phlegmon during the first surgery indicated Staphylococcus epidermidis.

After 19 days of hospitalization, due to the diagnosis of pleural tuberculosis, the patient was transferred to the Centre of Treatment of Lung Diseases and Tuberculosis in Łódź for further specialist treatment.

\section{Discussion}

Pleural diseases with pleural effusions are a common problem in pulmonary practice. Tuberculosis (TB) can be one of the causes of exudative effusions $[4,6]$. Pleural involvement may be primary or secondary to pulmonary TB (e.g. miliary TB) or post primary (reactivation) TB pleurisy. Among the extrapulmonary presentations of TB, pleural TB is noted in the second place only after lymphadenitis tuberculosis [5]. In the study of Ilgazli et al. [7], tuberculous pleurisy constituted $31.1 \%$ of all cases of extrapulmonary tuberculosis. Pleural TB is most frequently seen in adolescents and adults over 50 years of age as a complication of primary TB. The effusion generally develops on the same side as the initial infection and is typically unilateral, most often in association with parenchymal and/or nodal abnormalities [8, 9]. A similar clinical picture was observed in our patient. The changes observed in radiological diagnostics, e.g. fluid, pleural thickening, were related only to the left pleural cavity.

The diagnosis of tuberculosis pleural effusion (TPE) can be difficult to make because of the low positivity of various diagnostic tests. Classic diagnostics are supported except CPB by thoracoscopy or pleuroscopy, which is commonly performed after one or two thoracocenteses and at least one nondiagnostic CPB $[10,11]$. The complications of thoracoscopy are rarely described $[11,12]$. Overall complication rates for thoracoscopy are $1 \%$ to $5 \%$; however, most are minor and do not prolong hospital stay [3]. Serious complications include death, severe hemorrhage, sepsis, pulmonary embolism, hypercapnic coma and empyema [11]. The group of less severe complications comprises clinically insignificant pneumothorax, prolonged air leakage, subcutaneous emphysema, pneumonia, non-infectious fever, and pain requiring opiates. The mortality rate published from large centers performing pleuroscopy does not exceed the value of $0.8 \%$ [3]. In the studies of Blanc et al., among 154 patients subjected to thoracoscopy at least 1 complication occurred in $22.6 \%$ of them, but only $5.4 \%$ of the patients required active medical management during the hospital stay [11]. Thoracoscopy is recommended to be avoided in the case of an active form of pleural TB due to the possibility of further spread of the disease [13]. The case of our patient was unique, which is why we think it is worth noting. Within 2 days after pleuroscopy there developed cervical fasciitis with accompanying symptoms of mediastinitis. In the classic descending necrotizing mediastinitis (DNM), infections originating in the fascial planes of the head and neck spread downward into the mediastinum along the cervical fascia, facilitated by gravity, breathing and negative intrathoracic pressure $[14,15]$. Descending necrotizing mediastinitis of bacterial etiology is characterized by rapid course. Locally, there develop changes such as abscesses, empyema, pleuropericardial effusion, intrathoracic hemorrhage, cardiac tamponade and others. The ongoing inflammatory process causes sepsis and activates systemic reactions, with a fatal outcome [16]. Mortality rates reported in recent literature in DNM are very high, between $25 \%$ and $60 \%$ in different series $[17,18]$. Toilette, debridement, drainage of infected fluid collections and necrotic tissue exeresis are the surgical gold standard therapy but the best surgical approach to this operation remains controversial.

We suspect that in our patient mediastinal infection occurred due to damage of mediastinal pleura during biopsy in the "ascending" mechanism and to further spread of the infection through fascial spaces to the neck. Induction of pneumothorax with carbon monoxide insufflation during pleuroscopy was the contributing factor. As regards anatomy, infection spreading from the pleural cavity is possible because the middle layer of the deep cervical fascia fuses with the parietal pericardium at the level of the tracheal bifurcation and attaches to the mediastinal pleura [17, 19]. Earlier antibiotic therapy and thoracocentesis performed three times in a patient with a weakened immune system in the course of tuberculous pleurisy could contribute to iatrogenic infection of the pleural cavity and to a poorly symptomatic course. Sarr et al. reported that pathogens found in medical personnel and the equipment used in the operating room, among which there dominate coagulase-negative infections with Staphylococcus strains, are an important source of infections of iatrogenic etiology [20]. It is possible that in our patient the infection of the pleural cavity with this bacterial strain may have originated in the course of earlier performed thoracocenteses. 
To avoid this unusual complication after thoracoscopy it is necessary to exclude tuberculosis and active infection in the pleural space before the procedure. Administration of carbon monoxide to the non-sterile pleural cavity can lead to the spread of mediastinal infection in an ascending mechanism.

\section{Literature}

1. Legha SS, Muggia FM. Pleural mesothelioma: clinical features and therapeutic implications. Ann Intern Med 1977; 87: 613-621.

2. Mårtensson G, Pettersson K, Thiringer G. Differentiation between malignant and non-malignant pleural effusion. Eur J Respir Dis 1985; 67: 326-334.

3. Michaud G, Berkowitz DM, Ernst A. Pleuroscopy for diagnosis and therapy for pleural effusions. Chest 2010; 138: 1242-1246.

4. Epstein DM, Kline LR, Albelda SM, Miller WT. Tuberculosis pleural effusions. Chest 1987; 91: 106-109.

5. Villegas MV, Labrada LA, Saravia NG. Evaluation of polymerase chain reaction, adenosine deaminase, and interferon-gamma in pleural fluid for the differential diagnosis of pleural tuberculosis. Chest 2000; 18: 1355-1364.

6. Soe Z, Shwe WH, Moe S. A study on tuberculous pleural effusion. International Journal of Collaborative Research on Internal Medicine \& Public Health 2010; 2: 32-48.

7. Ilgazli A, Boyaci H, Basyigit I, Yildiz F. Extrapulmonary tuberculosis: clinical and epidemiologic spectrum of 636 cases. Arch Med Res 2004; 35: 435-441.

8. Curvo-Semedo L, Teixeira L, Caseiro-Alves F. Tuberculosis of the chest. Eur J Radiol 2005; 55: 158-172.

9. Mougdil H, Sridhar G, Leitch AG. Reactivation disease: the commonest form of tuberculous pleural effusion in Edinburgh, 1980-1991. Respir Med 1994; 88: 301-304.
10. Harris RJ, Kavuru MS, Mehta AC, Medendorp SV, Wiedemann HP, Kirby TJ, Rice TW. The impact of thoracoscopy on the management of pleural disease. Chest 1995; 107: 845-852.

11. Blanc FX, Atassi K, Bignon J, Housset B. Diagnostic value of medical thoracoscopy in pleural disease: a 6-year retrospective study. Chest 2002; 121 : 1677-1683.

12. Colt HG. Thoracoscopy: a prospective study of safety and outcome. Chest 1995; 108: 324-329.

13. Emad A, Rezaian GR. Diagnostic value of closed percutaneous pleural biopsy vs pleuroscopy in suspected malignant pleural effusion or tuberculous pleurisy in a region with a high incidence of tuberculosis: a comparative, age-dependent study. Respir Med 1998; 92:488-492.

14. Rokicki M, Rokicki W, Rokicki M Jr. Zstępujące martwicze zapalenie śródpiersia - postępowanie diagnostyczne i leczenie chirurgiczne. Kardiochir Torakochir Pol 2006; 3: 389-393.

15. Papalia E, Rena O, Oliaro A, Cavallo A, Giobbe R, Casadio C, Maggi G, Mancuso M. Descending necrotizing mediastinitis: surgical management. Eur J Cardiothorac Surg 2001; 20: 739-742.

16. Sancho LM, Minamoto H, Fernandez A, Sennes LU, Jatene FB. Descending necrotizing mediastinitis: a retrospective surgical experience. Eur J Cardiothorac Surg 1999; 16: 200-205.

17. Freeman RK, Vallières E, Verrier ED, Karmy-Jones R, Wood DE. Descending necrotizing mediastinitis: an analysis of the effects of serial surgical debridement on patient mortality. J Thorac Cardiovasc Surg 2000; 119: 260-267.

18. Ridder GJ, Maier W, Kinzer S, Teszler CB, Boedeker CC, Pfeiffer J. Descend ing necrotizing mediastinitis: contemporary trends in etiology, diagnosis, management, and outcome. Ann Surg 2010; 251: 528-534.

19. Marty-Ané $\mathrm{CH}$, Berthet JP, Alric $P$, Pegis JD, Rouvière $P$, Mary H. Management of descending necrotizing mediastinitis: an aggressive treatment for an aggressive disease, Ann Thorac Surg 1999; 68: 212-217.

20. Sarr MG, Gott VI, Townsend TR. Mediastinal infection after cardiac surgery. Ann Thorac Surg 1984; 38: 415-423. 